\title{
The Need to Register New Cultivar Names: Penstemon, a Case Study
}

\author{
D.T. Lindgren ${ }^{1}$ \\ Department of Horticulture, University of Nebraska West Central Research and Extension Center, \\ Route 4, Box 46A, North Platte, NE 69101
}

The genus Penstemon of cultivated landscape plants contains many species (Kartesz and Kartesz, 1980) and named horticultural selections (Lindgren and Davenport, 1992). However, of the 443 names listed in a recent publication summarizing Penstemon cultivar and selection names, only 29 (7\%) were registered with the American Penstemon Society's "Registrar of Cultivars" (Lindgren and Davenport, 1992). As with many ornamental crops, Penstemon cultivars are selected and developed by public and private plant breeders (professional and amateur) and other individuals. Many individuals who release and name Penstemon cultivars have little understanding of the cultivar release and registration process. Registering a new cultivar of a horticultural crop is useful and important, regardless of the crop's economic value. Registration guidelines and procedures should be followed by anyone who names a cultivar.

\section{Difficulties encountered when cultivar names are not registered}

Problems can occur when new cultivars of any genus are not registered. Using Penstemon as an example, I will highlight several of these problems.

Lack of parentage information. Not knowing the parentage of named cultivars can lead to research duplication. A summary of the genetic background of the 443 Penstemon names that have been compiled as of 1992 (Lindgren and Davenport, 1992) indicates that the parentage of about one-third (148) of the listed cultivars is unknown (Table 1). One hundred sixty-five are listed as having a single species parent. Fifty are listed as $P$. barbatus or $P$. barbatus hybrids. Sixteen of these hybrids are listed as having 'Flathead Lake' background; 19 are listed as having "Gloxinoides" origin, which is described as either a $P$. hartwegii $\times$ P. cobaea hybrid or a $P$. hartwegii variant; 60 are listed as specific crosses between two parents (other than $P$. barbatus and "Gloxinoides"); and one selection is listed as a three-way hybrid. Cultivar name, pedigree, and general characteristics

Received for publication 8 May 1992. Accepted for publication 19 Oct. 1992. Published as paper no. 9920, Journal Series, Agricultural Research Division, Univ. of Nebraska, Lincoln. The cost of publishing this paper was defrayed in part by the payment of page charges. Under postal regulations, this paper therefore must he hereby marked advertisement solely to indicate this fact.

'Associate Professor; Registrar of Cultivars, American Penstemon Society. must be known before a new cultivar can be used intelligently in a breeding program (Lyrene, 1990). With a genus such as Penstemon, for which relatively few genetic studies have been published, it is even more critical to have background knowledge of all cultivars to help make initial breeding strategy decisions. This information could come from registration records if the cultivars were registered properly.

Misspelled names. Misspelling names may cause one cultivar to be listed as one or more similarly spelled cultivars. Some similarly spelled cultivar names in the Penstemon genus are 'Alice Hindley' vs. 'Alice Handley'; 'Middleton Gem' vs. 'Middleton Gen.' vs. 'Myddelton Gem'; 'George Holmes' vs. 'George Home'; 'Hewell's Pink' vs. 'Howell's Pink'; and 'Gadwood Hybrids' vs. 'Gladwood Hybrids'. Are these different cultivars with similarly spelled names or are they the same cultivar with a misspelled name? We do not know. Crosswhite (1967) discussed spelling variants for the genus Penstemon (Penstemon vs. Pentstemon vs. Pentastemun vs. Penstastemon) and indicated that mere spelling differences do not create new names. The same applies to cultivar names. He also stated that "It is only natural for a bibliographer to list each spelling variant separately, merely because he does not know for certain whether separate names are involved or not." If a name were registered, much of this spelling confusion could be eliminated.

Duplicated names. If names are not registered, they may be duplicated. In the genus Penstemon, 'Snowflake', 'Blue Springs', and 'Castle Forbes' seem to have duplicate origins.

Inadequate description. An individual can only guess from a name what a selection might look like if it is not registered and an adequate description and genetic background are not included. About $20 \%$ of the Penstemon cultivar names refers to a color that describes the flower; $\approx 80 \%$ of the cultivar names listed gives little information on flower color or other plant traits (Table 1). Names that refer to a place (15.6\%), such as 'Broken Top Mountain', 'Duncan Ranch', and 'Lost Lake Hybrid', and names that refer to a person (19.6\%), such as 'Captain Penwall', 'Claude Barr', and 'Olga', are of no value in describing flowers or foliage (Table 1).

Similarly, it would be interesting to know why certain names were chosen for specific selections. For example, 'Martha Raye' is listed as being so named because of an extra wide "mouth" on the flower. Would this name selection criterion also apply to cultivars such as 'Creeping Thelma', 'Thorn', or 'Little
Chunky'? Why were names like 'My Pet', 'Waxworks', 'Sour Grapes', and 'Black Bird' selected?

Incorrect nomenclature. Sometimes the correct scientific nomenclature is not used in describing or listing a plant. In the summarized list of Penstemon cultivar names (Lindgren and Davenport, 1992), several species names that are not recognized species according to Kartesz and Kartesz (1980) were used to describe cultivar parentage. Correct nomenclature is essential for good communication in the plant trade. The role of scientific nomenclature for perennials has been discussed (Flint, 1991). Corrections in nomenclature can be made at the time of registration.

Lack of propagation information. Registering a cultivar provides a written description of the cultivar plus other information, such as propagation method and originator. 'Husker Red' Penstemon was released originally as a vegetatively propagated plant with red foliage (Lindgren, 1984). It is occasionally propagated by seed in the nursery industry. However, it can easily cross pollinate with plants of the same species that have green foliage, a cross that results in progeny that do not have the parent's red foliage. Propagation methods, along with other information, are usually included in registration information.

Lack of differentiation among new releases. Problems can occur when contemplating the release of anew cultivar with respect to whether similar selections have already been released. A registered cultivar usually includes a detailed description in the registration records, therefore making comparisons possible. For example, two Penstemon hybrids are listed as having a parentage of $P$. cobaea $\times$. triflorus

Table 1. Summary of sources of Penstemon cultivar names.

\begin{tabular}{lrc}
\hline Source & $\begin{array}{c}\text { Total } \\
\text { no. }\end{array}$ & $\begin{array}{c}\text { Percent } \\
\text { total }\end{array}$ \\
\hline No parents listed & 148 & 33.4 \\
Single species selection & 165 & 37.3 \\
$P$. barbatus hybrids & 50 & 11.3 \\
Flathead Lake & 16 & 3.6 \\
Gloxinoides types & 19 & 4.3 \\
Two parents & 60 & 13.5 \\
Three-way hybrid & 1 & 0.2 \\
Total & 443 & 100 \\
Color listed in name & 91 & 20.5 \\
Place listed in name & 69 & 15.6 \\
Person's name as & & \\
$\quad$ cultivar's name & 87 & 19.6 \\
\hline
\end{tabular}

Based on Lindgren and Davenport (1992).

${ }^{y}$ Flathead Lake selections are also included in $P$. barbatus hybrids. 
('Henry' and 'Gurney' hybrids). Neither hybrid is registered with the American Penstemon Society. The society's program is contemplating releasing a $P$. cobaea $\times$ P. triflorus hybrid. Because there is not a good detailed description of the 'Henry' and 'Gurney' hybrids and because original plants probably are no longer available, the society cannot determine if its selection is too similar to the 'Henry' or 'Gurney' hybrids to release the P. cobaea x P. triflorus hybrid.

\section{Registration requirements}

The international code of nomenclature for cultivated plants (Brickell, 1980) lists seven requirements that should accompany a cultivar registration request:

1) The name and address of the originator and the introducer (if any) or their assignees.

2) The name of the describer or namer, when the cultivar has been previously described or named, and a full reference to the date and place of publication.

3) The original name, if the name submitted for registration is a commercial synonym.

4) The parentage when known.

5) Particulars of tests for distinctness, including date and place of testing.

6) If awards are mentioned, their date.

7) A description, if none has been published.

These registration requirements are basic and should not be a hardship for anyone releasing a new cultivar.

\section{Why are many cultivars not registered?}

There are several possible reasons why cultivars are not registered, including the following:

- Individuals who release cultivars may not realize there is a registration authority for a particular genus.

- Individuals who release named cultivars may not understand the registration process and its importance.

- Individuals may feel the registration process serves no useful purpose.

- Individuals may feel they cannot document the parentage of a selection and, therefore, will not register it.

- Cultivars are sometimes named to honor someone when there is no intention of officially releasing the plant (Apps, 1991).

- Announcing a cultivar release in a journal or publication does not always substitute for registering the cultivar with the proper registration authority.

- Sometimes, named selections are not propagated in adequate numbers to be released. However, they still should be registered. If there are not adequate numbers for release, they probably should not be named in the first place.

- Individuals who release cultivars may not understand that a registration authority is international. It is not limited to one country or one continent. A directory of international registration authorities for horticul- ture cultivar names is available (Vrugtman, 1990) and contains the registration authority for specific plants.

Registration would eliminate much of the confusion that occurs with cultivar names of horticultural crops. We all need to do a better job of registering cultivar names.

\section{Literature Cited}

Apps, D.A. 1991. Selecting daylilies with commercial value. Perennial Plants, Nwsl. Perennial Plant Assn. 27:4-5.

Brickell, C.D. (ed.). 1980. International code of nomenclature for cultivated plants. vol. 104. Crop Sci. Soc., Madison, Wis.

Crosswhite, F.S. 1967. Against proliferation of superfluous names by giving formal status to spelling variants. Taxonomy 16:109-112.

Flint, H.L. 1991. The role of scientificnomenclature in the world of perennials. Proc. 1991 Perennial Plant Symp., Atlanta.

Kartesz, J.T. and R. Kartesz. 1980. A synonymized checklist of the vascular flora of the United States, Canada and Greenland. Univ. of North Carolina, Chapel Hill.

Lindgren, D. 1984. 'Husker Red' Penstemon. HortScience 19(3):459.

Lindgren, D.T. and B. Davenport. 1992. List and description of named selections in the genus Penstemon. Univ. of Nebraska Coop. Ext. EC 92-1246-D.

Lyrene, P. 1990. Description of cultivars: Science or advertising. HortScience 25(4):382-383.

Vrugtman, F. 1990. Directory of international registration authorities for cultivar names. HortScience 25(6):618-621. 